\title{
Regulation of Membrane Chloride Currents in Rat Bile Duct Epithelial Cells
}

\author{
J. Gregory Fitz, Srisaila Basavappa, James McGill, Ola Melhus, and Jonathan A. Cohn \\ Duke University and Veterans Administration Medical Center, Durham, NC 27710
}

\section{Abstract}

This study examines the conductive properties of the plasma membrane of cells isolated from the intrahepatic portion of bile ducts. Membrane $\mathrm{Cl}^{-}$conductance was measured in single cells using whole-cell patch clamp recording techniques and in cells in short-term culture using ${ }^{36} \mathrm{Cl}$ and ${ }^{125} \mathrm{I}$ efflux. Separate $\mathrm{Ca}^{2+}$ and cAMP-dependent $\mathrm{Cl}^{-}$currents were identified. $\mathrm{Ca}^{2+}$-dependent $\mathrm{Cl}^{-}$currents showed outward rectification of the current-voltage relation, time-dependent activation at depolarizing potentials, and reversal near the equilibrium potential for $\mathrm{Cl}^{-}$. Ionomycin $(2 \mu \mathrm{M})$ increased this current from $357 \pm 72 \mathrm{pA}$ to $1,192 \pm 414 \mathrm{pA}$ (at $+80 \mathrm{mV}$ ) in $5: 7$ cells, and stimulated efflux of ${ }^{125} \mathrm{I}>{ }^{36} \mathrm{Cl}$ in 15:15 studies. Ionomycin-stimulated efflux was inhibited by the $\mathrm{Cl}^{-}$channel blocker $4,4^{\prime}$-diisothiocyano-2,2'-stilbene disulfonic acid (DIDS) (150 $\mu \mathrm{M})$. A separate cAMP-activated $\mathrm{Cl}^{-}$current showed linear current-voltage relations and no time dependence. Forskolin $(10 \mu \mathrm{M})$ or cpt-cAMP $(500 \mu \mathrm{M})$ increased this current from $189 \pm 50 \mathrm{pA}$ to $784 \pm 196 \mathrm{pA}$ (at $+80 \mathrm{mV}$ ) in 11:16 cells, and stimulated efflux of ${ }^{36} \mathrm{Cl}>{ }^{125} \mathrm{I}$ in 16:16 studies. cAMP-stimulated efflux was unaffected by DIDS. Because the cAMP-stimulated $\mathrm{Cl}^{-}$conductance resembles that associated with cystic fibrosis transmembrane conductance regulator (CFTR), a putative $\mathrm{Cl}^{-}$ channel protein, the presence of CFTR in rat liver was examined by immunoblot analyses. CFTR was detected as a 150165-kD protein in specimens with increased numbers of duct cells. Immunoperoxidase staining confirmed localization of CFTR to bile duct cells but not hepatocytes. These findings suggest that $\mathrm{Ca}^{2+}$ - and $\mathrm{cAMP}$-regulated $\mathrm{Cl}^{-}$channels may participate in control of fluid and electrolyte secretion by intrahepatic bile duct epithelial cells, and that the cAMP-regulated conductance is associated with endogenous expression of CFTR. Abnormal ductular secretion may contribute to the pathogenesis of cholestatic liver disease in cystic fibrosis. $(J$. Clin. Invest. 1993.91:319-328.) Key words: liver • immunohistochemistry • cystic fibrosis • patch clamp • Western blot

\section{Introduction}

Bile formation is initiated by hepatic secretion into the canalicular space between hepatocytes. Recent observations indicate that the volume and composition of bile is subsequently modified within the lumen of intrahepatic bile ducts as a result of

Address correspondence to Greg Fitz, M. D., Box 3671, Room 307 Sands Building, Duke University Medical Center, Durham, NC 27710. Received for publication 26 December 1991 and in revised form 30 July 1992.

The Journal of Clinical Investigation, Inc.

Volume 91, January 1993, 319-328 primary secretion of fluid and electrolytes (1). In animal models, experimental maneuvers which increase the number of bile duct epithelial (BDE) ${ }^{1}$ cells result in parallel increases in bile flow (2-6). BDE cells resemble other secretory cells in that they are polarized with tight junctions and abundant apical microvilli $(7,8)$. More recently, evidence for independent regulation of ductular transport by the hormone secretin which binds to receptors on BDE cells but not hepatocytes has been presented $(6,9)$. These observations suggest that biliary secretion contributes importantly to bile formation, but the small size and intrahepatic location of these cells has limited efforts to characterize the physiologic mechanisms responsible.

Bile duct epithelial cells represent an important target of injury in several clinical disorders characterized by cholestasis including the genetic disease cystic fibrosis (10). In cystic fibrosis, mutations in the cystic fibrosis transmembrane conductance regulator (CFTR) result in a characteristic defect in cAMP-dependent regulation of $\mathrm{Cl}^{-}$channels (11-14) in lung, pancreas, and sweat gland (14-19). $\mathrm{Ca}^{2+}$-dependent regulation of $\mathrm{Cl}^{-}$channels appears to be unaffected. While hepatic cholestasis in cystic fibrosis could reflect changes in either hepatocyte or duct cell function, intracellular $\mathrm{Cl}^{-}$in hepatocytes appears to be near electrochemical equilibrium suggesting that transepithelial transport of $\mathrm{Cl}^{-}$is not likely to be the principal driving force for hepatocellular secretion (20). However, if BDE cells resemble the duct cells of other tissues, then transepithelial transport of $\mathrm{Cl}^{-}$ions may contribute to biliary secretion, and abnormalities of channel regulation may contribute to the clinical expression of cholestasis in CF and other diseases.

In these studies in isolated BDE cells, we have evaluated the mechanisms responsible for regulation of membrane $\mathrm{Cl}^{-}$transport to determine if BDE cells are similar to established $\mathrm{Cl}^{-}$ secretory epithelia. $\mathrm{Cl}^{-}$currents were measured in individual cells using whole-cell patch clamp techniques (21) and anion permeability was measured in cells in short-term culture using isotope efflux techniques (22). These studies demonstrate that increases in cytosolic $\mathrm{Ca}^{2+}$ and cAMP activate anion permeability pathways with distinct properties. In addition, immunoblot and immunohistochemical analyses indicate the presence of CFTR in bile duct cells but not hepatocytes (23-26). Thus, intrahepatic bile duct epithelial cells share many phenotypic features of established $\mathrm{Cl}^{-}$secretory cells, suggesting that regulation of distinct membrane $\mathrm{Cl}^{-}$channels by $\mathrm{Ca}^{2+}$ - and cAMPdependent signaling pathways may contribute to fluid and electrolyte secretion by these cells. Moreover, abnormalities in $\mathrm{Cl}^{-}$channel regulation could contribute to the cholestatic manifestations of $\mathrm{CF}$ and other primary disorders affecting intrahepatic bile ducts.

1. Abbreviations used in this paper: BDE, bile duct epithelial; CFTR, cystic fibrosis transmembrane conductance regulator; DIDS, 4-4'diisothiocyanoto-stilbene-2,2'-disulfonic acid; DPC, diphenylamine-2carboxylate. 


\section{Methods}

Cell isolation and culture. Epithelial cells were isolated from the intrahepatic portion of bile ducts from male Sprague-Dawley rats (200-250 g) 2-6 wk after bile duct ligation as recently described (27). Briefly, the biliary tree was isolated by collagenase perfusion, minced, and filtered sequentially through nylon monofilament screens with pore diameters of $253,100,60$, and $20 \mu \mathrm{m}$, and centrifuged on Percoll (Sigma Chemical Co., St. Louis, MO) gradients. Cells were washed, and subjected to a second Percoll gradient from which viable cells were collected between a density of 1.065 and $1.075 \mathrm{~g} / \mathrm{ml}$. Isolated cells were plated on $35-\mathrm{mm}$ collagen-coated plates in Leibowitz L-15 media supplemented with $10 \%$ fetal calf serum, $2 \%$ glutamine, and penicillin/streptomycin. Cells were maintained in a $5 \% \mathrm{CO}_{2}$ incubator at $37^{\circ} \mathrm{C}$.

Cell viability was routinely evaluated by trypan blue exclusion. Cell counts were performed on a hemocytometer and confirmed using a counter (Coulter Corp., Hialeah, FL). Gamma-glutamyl transpeptidase (GGT) histochemical staining was performed using a modified procedure described by Rutenberg (28). Protein concentration was assayed using the Lowry method with BSA as the standard (29). Monoclonal antibodies for CK-19, which recognize intermediate cytoskeletal filaments present in bile duct cells but not hepatocytes, were obtained from ICN Biomedical, Inc. (Costa Mesa, CA).

Detection of CFTR. CFTR immunoreactivity was detected using alpha-1468, a high affinity antibody raised against a synthetic peptide corresponding to the $\mathrm{COOH}$-terminal amino acid sequence of CFTR $(18,19,30)$. Preliminary studies have shown that this antibody recognizes CFTR in rat tissues (31) as predicted based on the observation that the deduced $\mathrm{COOH}$-terminal amino acid sequence of rodent CFTR is almost identical to the human sequence (32). For immunoblot analysis, tissue samples were solubilized in a buffer containing 60 mM Tris ( $\mathrm{pH}$ 6.8), 3\% SDS, $1 \mathrm{mM}$ PMSF, $5 \mathrm{mM}$ benzamidine, $1 \mathrm{mM}$ EDTA, $5 \mu \mathrm{g} / \mathrm{ml}$ leupeptin, and $50 \mathrm{mM}$ dithiothreitol. Samples were adjusted to contain equal amounts of protein (Micro BCA protein assay kit; Pierce Chemical Co., Rockford, IL) and proteins were resolved using $7 \%$ polyacrylamide gels and electrophoretically transferred as described (18). Immunoblots were performed using alpha1468 (1:100 final dilution) and immunoreactive proteins were detected by enhanced chemilluminesence (Amersham Corp., Arlington Heights, IL). Immunoperoxidase staining of liver specimens was performed as described $(18,19,30)$. Cryosections $(4 \mu \mathrm{m})$ were fixed in acetone for $10 \mathrm{~s}$ at room temperature, incubated in PBS containing $5 \%$ goat serum, and then incubated with alpha- 1468 in PBS (2-5 $\mu \mathrm{g} / \mathrm{ml}$ final concentration). Immunoperoxidase staining was performed using biotinylated goat anti-rabbit IgG (1:200) and a Vectastain Elite ABC kit (Vector Labs, Inc., Burlingame, CA). Specimens were counterstained with modified Harris hematoxylin.

Whole-cell recording. The whole-cell recording technique using patch clamp methods (21) was used to record macroscopic membrane currents in isolated cells in short-term culture (12-30 h) using an amplifier (Axopatch 1C or 1D; Axon Instruments, Burlingame, CA). Immediately before study, media in the culture dish was replaced with the $\mathrm{NaCl}$-rich electrolyte solution (see below), and cells were viewed at a magnification of 600 with Hoffman optics using an inverted phase contrast microscope (Olympus IMT-2). Recording pipettes were made from Corning 7052 glass, coated with Sylgard (Dow Corning Corp., Midland, MI), and had tip resistances of 3-7 megohms when filled with physiologic saline. Voltage commands and current measurements were performed using pCLAMP programs (Axon Instruments), a TL125 analogue-digital interface (Axon Instruments), and a Compaq 386 computer. Currents were filtered at $1 \mathrm{kHz}$ and sampled at $2 \mathrm{kHz}$. Recordings were not leak corrected unless otherwise noted. Voltages were referenced to a bath electrode, and outward membrane currents and membrane depolarization are shown as positive. For current-voltage plots, peak currents were measured $350-380 \mathrm{~ms}$ after the voltage step unless otherwise indicated.

Solutions and reagents. The $\mathrm{NaCl}$-rich bath solution contained (in $\mathrm{mM}) 140 \mathrm{NaCl}, 4 \mathrm{KCl}, 2 \mathrm{MgCl}_{2}, 1 \mathrm{CaCl}_{2}, 1 \mathrm{KH}_{2} \mathrm{PO}_{4}, 10$ glucose, and
10 Hepes $/ \mathrm{NaOH}(\mathrm{pH} \sim 7.30)$. The $\mathrm{KCl}$-rich pipette solution contained $130 \mathrm{KCl}, 10 \mathrm{NaCl}, 2 \mathrm{MgCl}_{2}, 0.1 \mathrm{ATP}, 10 \mathrm{Hepes} / \mathrm{KOH}(\mathrm{pH}$ $\sim 7.30$ ), and $0.5 \mathrm{CaCl}_{2}$ and 1 EGTA. The calculated equilibrium potentials for $\mathrm{K}+$ and $\mathrm{Cl}^{-}$are $-83 \mathrm{mV}$ and $-1 \mathrm{mV}$, respectively. The estimated free $\mathrm{Ca}^{2+}$ concentration was $\sim 100 \mathrm{nM}(33)$ which compares to values between 60 and $120 \mathrm{nM}$ measured in cells in culture using fura-2 (unpublished observations). Low $\mathrm{Cl}^{-}$solutions were obtained by isosmotic substitution with gluconate.

Test reagents were added directly to the bath ( vol $1 \mathrm{ml}$ ) as $20 \mu \mathrm{l}$ of concentrated test solution. 8-(4-chlorophenylthio)-adenosine 3':5'cyclic monophosphate, a membrane-permeant analogue of cAMP, was obtained from Sigma Chemical Co. (St. Louis, MO), dissolved in bath solution, and used at a final concentration of $500 \mu \mathrm{M}$. Stock solutions in DMSO of forskolin and ionomycin obtained from Calbiochem Corp. (La Jolla, CA) were used in final concentrations of $10 \mu \mathrm{M}$ for forskolin and $2 \mu \mathrm{M}$ for ionomycin. DMSO alone in equal concentrations added to the bath had no effect on membrane currents. The $\mathrm{Cl}^{-}$ channel blocker diphenylamine-2-carboxylate (DPC) was obtained from Pfaltz and Bauer Inc. (Waterbury, CT), dissolved in DMSO, and added to the bath to give a final concentration of $500 \mu \mathrm{M}$. 4,4'diisothiocyanato-stilbene-2,2'-disulfonic acid (DIDS) was obtained from Sigma Chemical Co. (St. Louis, MO), dissolved in extracellular buffer, and used in a final concentration of $150 \mu \mathrm{M}$. Tetraethyl ammonium chloride was obtained from Sigma Chemical Co., dissolved in $\mathrm{NaCl}$-rich buffer, and used in final concentrations of 2-4 mM. Results are presented as mean $\pm \mathrm{SE}$ where $n$ represents the number of cells studied.

Measurement of isotope efflux. ${ }^{36} \mathrm{Cl}$ and ${ }^{125} \mathrm{I}$ were obtained from Amersham Corp. and used to assess regulated anion efflux in cells in short-term culture in 22-mm wells (22). Experiments were performed $\sim 1 \mathrm{~d}$ after plating. Cells were incubated in the $\mathrm{NaCl}$-rich buffer containing $5-10 \mu \mathrm{Ci} / \mathrm{ml}$ of one or both isotopes as indicated for $60 \mathrm{~min}$. After loading, cells were washed with isotope-free buffer $(\sim 2 \mathrm{ml})$ three times over $2 \mathrm{~min}$. Subsequently, $1-\mathrm{ml}$ aliquots of buffer were added and removed at 30-s intervals. Timed samples of efflux buffer were measured in a gamma counter for ${ }^{125} \mathrm{I}$ alone or a scintillation counter (Beckman Instruments, Carlsbad, CA) using standard correction techniques for ${ }^{125} \mathrm{I}$ and ${ }^{36} \mathrm{Cl}$. The effects of experimental agents on isotope efflux were determined by direct addition to the buffer solution during the test period. Ionomycin $(2 \mu \mathrm{M})$ was used to increase intracellular $\mathrm{Ca}^{2+}$, and a cocktail containing forskolin $(10 \mu \mathrm{M})$ and 8-(4-chlorophenylthio-cAMP $(500 \mu \mathrm{M})$ was used to increase intracellular cAMP. At the end of an experiment, cells were lysed by exposure to $0.1 \mathrm{~N}$ $\mathrm{NaOH}$ and the sample counted to determine the amount of isotope remaining in the cell. Efflux rate at each time point was expressed as a ratio of counts at that time point divided by the total remaining counts (22). All studies were performed in triplicate on three or more study days, and results are presented as mean \pm SE where $n$ represents the number of individual culture wells.

\section{Results}

Characterization of isolated cells. The properties of isolated intrahepatic duct cells have recently been described (27). 80$95 \%$ of each preparation consisted of a homogenous population of small $(9.5 \pm 1.6 \mu \mathrm{m}, n=50)$ round cells. These were readily distinguished from hepatocytes by their size and morphology. Transmission electron microscopy revealed apical microvilli and a large nucleus with densely staining chromatin and relatively scant cytoplasm. $91 \pm 6 \%$ of cells excluded trypan blue, $93 \pm 2 \%$ stained positively for gamma-glutamyl transpeptidase, and $91 \pm 7 \%$ stained positively for CK-19, consistent with reported characteristics of intrahepatic BDE cells (2-8). In 20 monolayers assessed after $24 \mathrm{~h}$ in culture, $88 \pm 6 \%$ excluded trypan blue and $85 \pm 4 \%$ retained positive staining for gamma-glutamyl transpeptidase. Viability in cultured cells was 
A

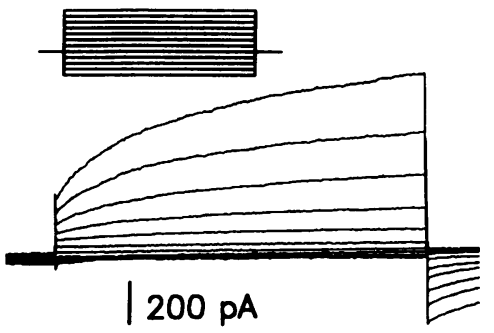

$50 \mathrm{~ms}$

B

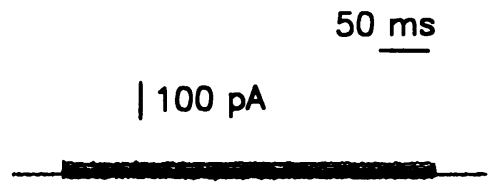

C

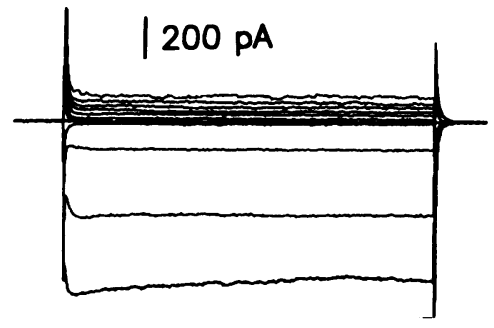

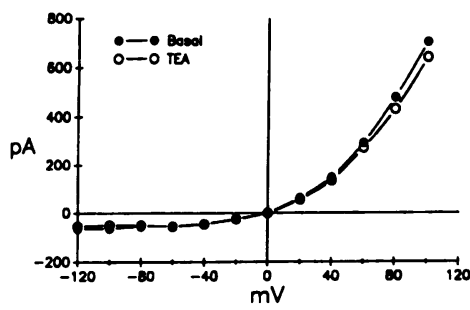
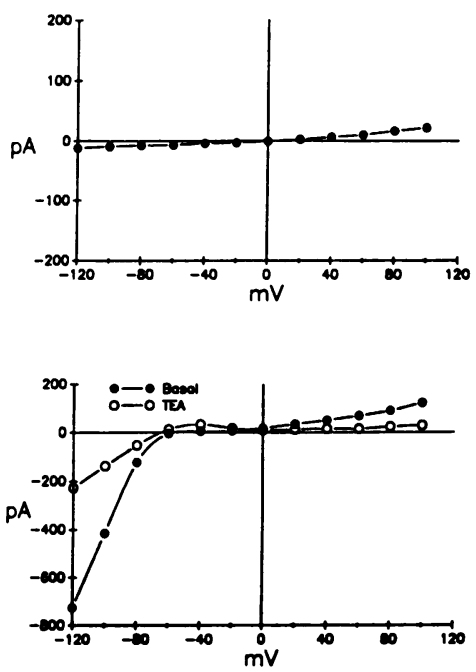

Figure 1. Whole cell currents. With $\mathrm{NaCl}$-rich solution in the bath and $\mathrm{KCl}$-rich solution in the pipette, membrane voltage was held at -40 $\mathrm{mV}$ and stepped to test potentials values between $-120 \mathrm{mV}$ and $+100 \mathrm{mV}$ in $20 \mathrm{mV}$ increments (inset). Three patterns of current response were distinguishable. $57 \%$ of cells exhibited time-dependent activation of currents after depolarizing voltage steps and outward rectification of the current-voltage relation $(A) ; 31 \%$ of cells exhibited small linear current responses $(B)$; and $12 \%$ exhibited inward rectification of the current-voltage relation $(C)$. Filled circles indicate basal measurements and open circles indicate measurements 2 min after exposure to $4 \mathrm{mM}$ TEA. unaffected by short-term exposure to low $\mathrm{Cl}^{-}$buffer, ionomycin, DPC, DIDS, or tetraethylammonium chloride as compared to matched plates (measured in triplicate). Most cells that were trypan blue positive or GGT negative could be distinguished from the predominant population of viable BDE cells and would not have been selected for patch clamp recording.

Whole cell currents. Isolated cells located near larger cell clusters were selected for most studies to minimize the contribution of cell-to-cell coupling. After formation of a high resistance seal between the pipette and the cell membrane (typically 5-25 Gohm), brief suction pulses were applied to rupture the small patch of membrane isolated by the pipette tip. Access to the cell interior was identified by an abrupt increase in the capacitance transient which averaged $6.0 \pm 3.1 \mathrm{pF}(n=55)$. Immediately after cell entry, membrane potential was between -30 and $-50 \mathrm{mV}$. In most cases, the cell rapidly depolarized as the pipette solution equilibrated with the cell interior. Voltage dependence of membrane currents was assessed by applying hyperpolarizing and depolarizing voltage steps $400 \mathrm{~ms}$ in duration from a holding potential of $-40 \mathrm{mV}$ to test potentials between -120 and $+100 \mathrm{mV}$ in $20 \mathrm{mV}$ increments with $2 \mathrm{~s}$ between steps (inset, Fig. 1). Although cells were morphologically indistinguishable, three patterns of current response were detected. Among 42 cells, 24 (57\%) showed outward rectification of the current-voltage relation (Fig. $1 A) ; 13(31 \%)$ showed small currents with a linear current-voltage relation (Fig. $1 \mathrm{~B}$ ); and $5(12 \%)$ showed inward rectification of the current-voltage relation (Fig. $1 C$ ). The ionic basis of these currents was evaluated further.

Outwardly rectifying currents. In the majority (57\%) of cells, voltage steps to values between $-120 \mathrm{mV}$ and $0 \mathrm{mV}$ elicited small inward currents that changed linearly with the test potential with a chord conductance of $0.73 \pm 0.19 \mathrm{nS}$ at -80 $\mathrm{mV}$. Depolarizing voltage steps elicited much larger outward currents which increased with the magnitude of the test pulse resulting in outward rectification of the current-voltage relation with chord conductances of $2.12 \pm 0.60 \mathrm{nS}$ at $+40 \mathrm{mV}$ and $4.96 \pm 1.02 \mathrm{nS}$ at $+80 \mathrm{mV}$ (Figs. $1 A$ and 2). Time-dependent activation of currents was apparent at potentials above +20 $\mathrm{mV}$. In 14 cells with peak currents above $300 \mathrm{pA}$ at $+80 \mathrm{mV}$, currents increased from $269 \pm 69 \mathrm{pA}$ measured $20 \mathrm{~ms}$ after the voltage step to $542 \pm 135 \mathrm{pA}$ measured $320 \mathrm{~ms}$ after the voltage

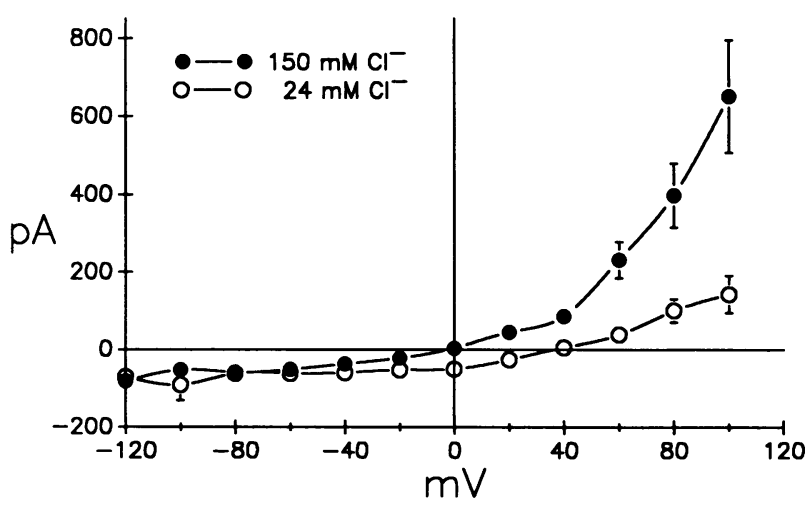

Figure $2 . \mathrm{Cl}^{-}$dependence of outward membrane currents. The average current-voltage relation of 14 cells with outwardly rectified currents measured as peak currents $350-380 \mathrm{~ms}$ after the test pulse is shown. With equal pipette and bath $\mathrm{Cl}^{-}$concentrations, currents reversed at $-2.3 \pm 5.8 \mathrm{mV}$ (filled circles). Lowering bath $\mathrm{Cl}^{-}$by substitution of gluconate decreased outward currents and shifted the reversal potential to $+37 \pm 5 \mathrm{mV}$ (open circles, $n=4$ ). 
step. Current activation at $+80 \mathrm{mV}$ could be described by a single exponential with a time constant of $185 \pm 28 \mathrm{~ms}$.

While the outward current could result from efflux of $\mathrm{K}+$ ions or influx of $\mathrm{Cl}^{-}$ions, several observations suggest that the contribution of $\mathrm{Cl}^{-}$predominates. First, the reversal potential for whole cell currents was $-2.3 \pm 5.8 \mathrm{mV}$, which agrees well with the equilibrium potential of $-1 / \mathrm{mV}$ for $\mathrm{Cl}^{-}$ions. Second, when bath $\mathrm{Cl}^{-}$concentration was lowered from 150 to $24 \mathrm{mM}$ by substitution with the impermeant anion gluconate, there was inhibition of the outward current to $99 \pm 35 \mathrm{pA}$ at $+80 \mathrm{mV}$ and the reversal potential shifted to $+37 \pm 5 \mathrm{mV}(n=4$, Fig. 2$)$. A shift of $47 \mathrm{mV}$ would be expected for a perfectly $\mathrm{Cl}^{-}$selective membrane in the absence of any leak conductance. Finally, exposure to the $\mathrm{K}+$ channel blocker TEA ( $4 \mathrm{mM})$ had no effect on the amplitude of the outward current or reversal potential (Fig. $1 A, n=4$ ). By contrast, exposure to the $\mathrm{Cl}^{-}$channel blocker DPC $(500 \mu \mathrm{M})$ resulted in rapid inhibition currents at $+80 \mathrm{mV}$ by $65 \pm 15 \%(n=5$, Fig. 4$)$.

To further evaluate $\mathrm{Cl}^{-}$selectivity, currents were activated by applying prepulses to $+80 \mathrm{mV}$ or $+100 \mathrm{mV}$ and then analyzed by measuring of instantaneous tail currents when the voltage was returned to different test potentials as illustrated in Fig. 3. The reversal potential as determined from the currentvoltage relationship of the tail currents was measured in different bath $\mathrm{Cl}^{-}$concentrations. With standard pipette and bath solutions, tail currents reversed at $+2.3 \pm 5.1 \mathrm{mV}(n=10)$ near the theoretical reversal potential for $\mathrm{Cl}^{-}(-1 \mathrm{mV})$. Lowering bath $\mathrm{Cl}^{-}$to $24 \mathrm{mM}$ caused a shift in the reversal potential to $+35.7 \pm 2.6 \mathrm{mV}(n=4)$. The dependency of the reversal potential on bath $\mathrm{Cl}^{-}$concentration (Fig. $3 C$ ) showed a slope of $\sim 42 \mathrm{mV}$ per log change in $\mathrm{Cl}^{-}$concentration as compared to the ideal Nerstian slope for a $\mathrm{Cl}^{-}$selective current $58 \mathrm{mV}$, confirming that the majority of the outward current is carried by $\mathrm{Cl}^{-}$ions. Despite the outward rectification of whole cell currents, the current-voltage relation of tail currents was linear. A similar relationship has been described for $\mathrm{Ca}^{2+}$-activated $\mathrm{Cl}^{-}$currents in T84 cells (14).

Small linear and inwardly rectifying currents. 13:42 (31\%) of cells exhibited small linear currents with peak values $<100$ pA (Fig. $2 \mathrm{~B}$ ). Reversal potentials after equilibration were more variable and averaged $-8.7 \pm 10.8 \mathrm{mV}$ with a range of $-30 \mathrm{mV}$ to $+3 \mathrm{mV}$. The ionic basis of these unstimulated currents could not be determined due to their small amplitude and variable reversal potential.

$5: 42(12 \%)$ of cells showed a markedly different current pattern where hyperpolarizing voltage steps elicited large inward currents $(-380 \pm 60 \mathrm{pA}$ at $-100 \mathrm{mV})$ and depolarizing voltage steps elicited small outward currents $(+45 \pm 60 \mathrm{pA}$ at $+100 \mathrm{mV}$, Fig. 1 C). Inward currents were maximal immediately after the voltage step and showed little time dependence. Although only a limited number of cells were evaluated, several observations suggest that the inward current is carried by $\mathrm{K}^{+}$ions. First, the reversal potential of whole cell currents was $-62.5 \pm 10.4 \mathrm{mV}$, more negative than in the majority of the cells studied. Second, in two cells, exposure to the $\mathrm{K}^{+}$channel blocker TEA $(4 \mathrm{mM})$ decreased currents at $-100 \mathrm{mV}$ by $68 \%$ and $76 \%$ (Fig. $1 C$ ). Finally, when currents were activated by a prepulse to -80 or $-100 \mathrm{mV}$ and then analyzed by evaluation of tail currents at varying test potentials, the reversal potential of the tail currents averaged $-71 \pm 5 \mathrm{mV}(n=3)$. This compares to the theoretical reversal potential of $\mathrm{K}^{+}$of $-83 \mathrm{mV}$.

Effect of intracellular $\mathrm{Ca}^{2+}$ and $c A M P$. In view of the important role of intracellular $\mathrm{Ca}^{2+}$ and cAMP in the regulation of certain $\mathrm{Cl}^{-}$channels $(13,14,16,17,34,35)$, we evaluated

A
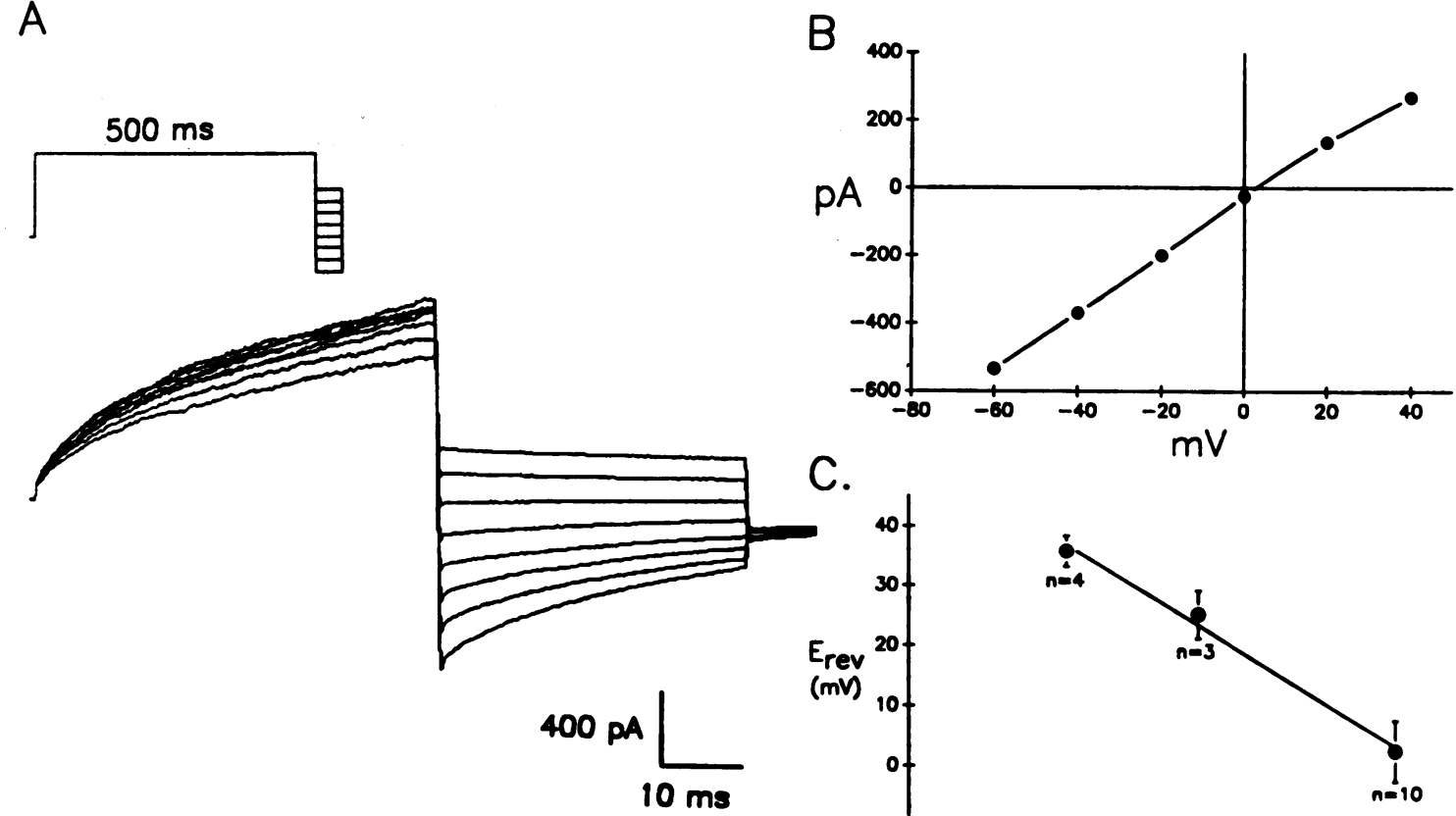

C.

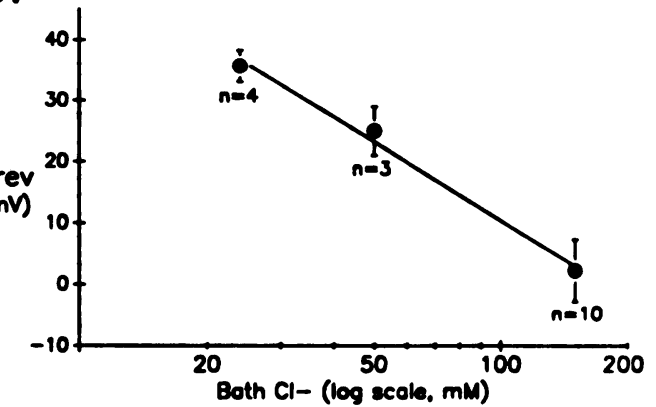

Figure 3. Analysis of tail currents. After a prepulse to $+80 \mathrm{mV}$ for $0.5 \mathrm{~s}$ to activate outward currents, pipette voltage was changed to test potentials between +40 and $-60 \mathrm{mV}$ ( inset, $A$ ). The currents $(A)$ and corresponding current-voltage relation $(B)$ are shown. With standard solutions tail currents measured $\sim 2 \mathrm{~ms}$ after the test pulse to eliminate the contribution of capacitance transients reversed near the equilibrium potential for $\mathrm{Cl}^{-}$. Lowering bath $\mathrm{Cl}^{-}$concentration caused a change in reversal potential of $\sim 42 \mathrm{mV}$ per log change in bath $\mathrm{Cl}^{-}$concentration $(C)$. 
whether maneuvers designed to increase $\mathrm{Ca}^{2+}$ or cAMP would alter basal currents. Outwardly rectified currents were not detected when cytosolic $\mathrm{Ca}^{2+}$ concentration was decreased to $<10 \mathrm{nM}$ by increasing pipette EGTA to $5 \mathrm{mM}(n=5)$. In contrast, exposure to the $\mathrm{Ca}^{2+}$ ionophore ionomycin $(2 \mu \mathrm{M})$ rapidly increased currents in 5:7 (71\%) cells from $357 \pm 72 \mathrm{pA}$ to $1,192 \pm 414 \mathrm{pA}$ at $+80 \mathrm{mV}$. As shown in Fig. 4, ionomycinstimulated currents exhibited time-dependent activation at depolarizing potentials and outward rectification. In standard solutions, ionomycin-stimulated currents reversed at $-0.6 \pm 2.6$ $\mathrm{mV}(n=5)$, and tail currents reversed at $0.9 \pm 10.0 \mathrm{mV}(n=3)$. In addition, stimulated currents were inhibited $68 \pm 15 \%(n$ $=3$ ) by exposure to DPC ( $500 \mu \mathrm{M}$, Fig. $4 A$ ). These features indicate that the $\mathrm{Ca}^{2+}$-activated current is carried by $\mathrm{Cl}^{-}$ions with properties similar to the outwardly rectifying current observed under basal conditions.

Exposure to forskolin ( $10 \mu \mathrm{M})$, which stimulates adenylyl cyclase $(n=4)$, or to cpt-cAMP $(500 \mu \mathrm{M})$, a membrane permeant analogue of cAMP $(n=12)$, increased membrane currents in 11:16 (69\%) cells from $189 \pm 50 \mathrm{pA}$ to $784 \pm 196 \mathrm{pA}$ at $+80 \mathrm{mV}$. In contrast to $\mathrm{Ca}^{2+}$-activated currents, in 9:11 responding cells the cAMP-dependent current had linear current-voltage relations, and there was no apparent time dependence, with full activation at the onset of the test potential (Fig. $5 \mathrm{~A}$ ). In these cells both the current-voltage relation and tail currents reversed near the $\mathrm{Cl}^{-}$equilibrium potential (values of $-3.6 \pm 1.6 \mathrm{mV}, n=9$, and $+3.0 \pm 3.4 \mathrm{mV}, n=5$, respec- tively), and currents at $+80 \mathrm{mV}$ were inhibited $74 \pm 15 \%$ by DPC $(n=4)$. In the remaining 2:11 responding cells, there was an increase in outwardly rectifying currents which were present under basal conditions. In the majority of these studies, seal integrity was confirmed by withdrawal of the electrode to form a high resistance excised patch, indicating that the increase in linear currents was not likely to be related to a change in seal resistance.

Isotope efflux. Ion substitutions were difficult to perform on these small cells due to loss of seal resistance. Consequently, complementary studies were performed in cells in culture to assess the effects of agonists on efflux of ${ }^{36} \mathrm{Cl}$ and ${ }^{125} \mathrm{I}$ as markers for activation of anion permeability (22). Representative results are shown in Fig. 6.

In the absence of agonists, efflux showed a rapid initial decline during the wash period (not shown) followed by a slower decrease over the remainder of the experimental period. The rapid initial loss appears to be caused by depletion of extracellular tracer while the slower decline is due to efflux of ${ }^{125} \mathrm{I}$ from a larger intracellular pool (22). Efflux from the slowly declining compartment could be fitted to a single exponential decay but there was significant variation among monolayers from different preparations. Consequently, stimulated efflux rates were compared to basal values in the same culture well to permit comparison between studies.

In cells loaded with both isotopes, exposure to ionomycin caused a simultaneous increase in efflux of ${ }^{36} \mathrm{Cl}$ and ${ }^{125} \mathrm{I}$ in
A

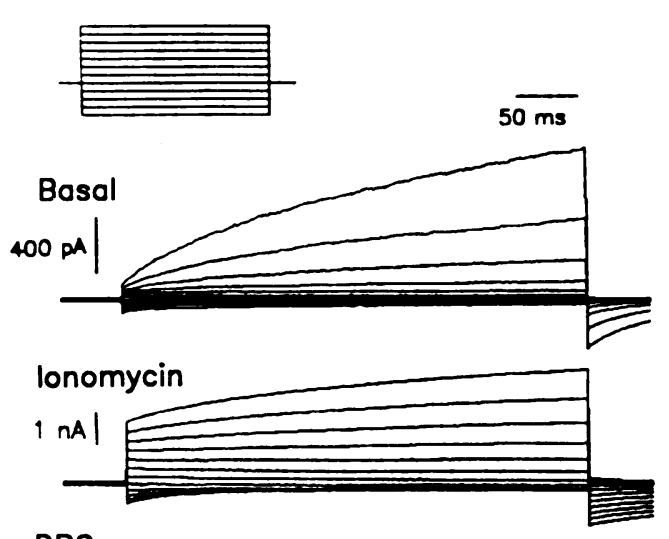

DPC

1 nAl
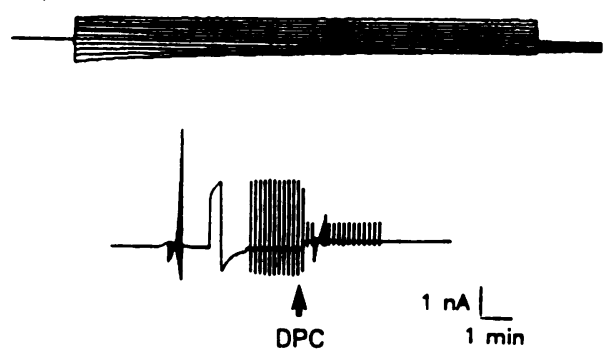

B

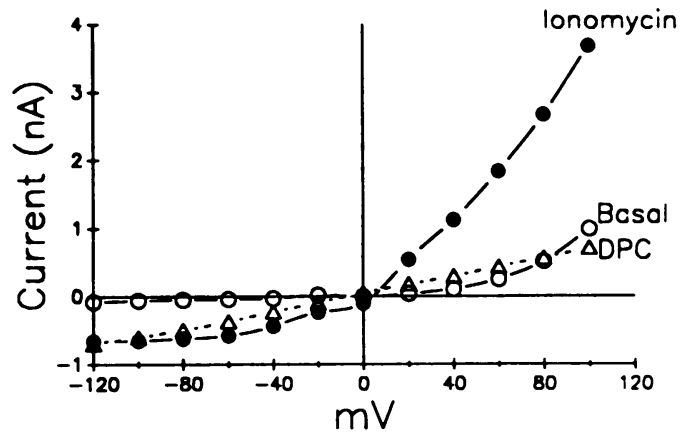

C

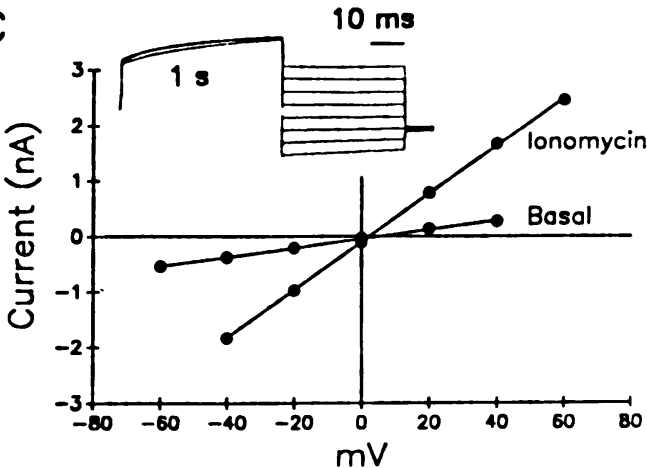

Figure 4. Effect of ionomycin on membrane currents. Membrane currents $(A)$ and the current-voltage relation $(B)$ were measured under basal conditions ( top in $A$, open circles in $B$ ), after exposure to ionomycin (middle in $A$, note change in scale, filled circles in $B$ ), and after exposure to DPC (bottom in $A$, open triangles in $B$ ). Exposure to ionomycin $(2 \mu \mathrm{M})$ caused a large increase in outward membrane currents. Stimulated currents $(B)$ as well as tail currents (inset, $C$ ) reversed near the equilibrium potential for $\mathrm{Cl}^{-}$and were inhibited by DPC ( $500 \mu \mathrm{M}$ ). The time course of DPC inhibition is illustrated in the lower tracing of panel A where currents during voltage steps from $-40 \mathrm{mV}$ to $+60 \mathrm{mV}$ at 10 -s intervals are shown. 

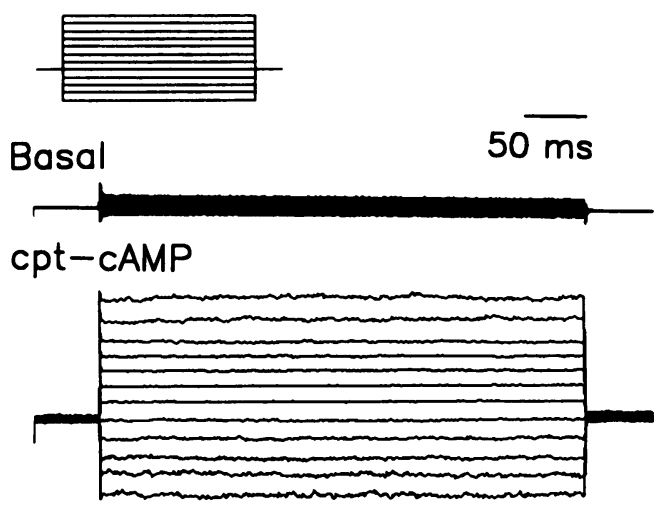

DPC

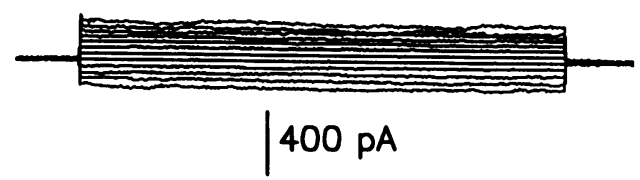

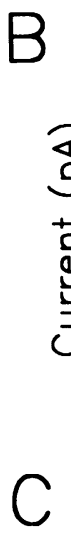
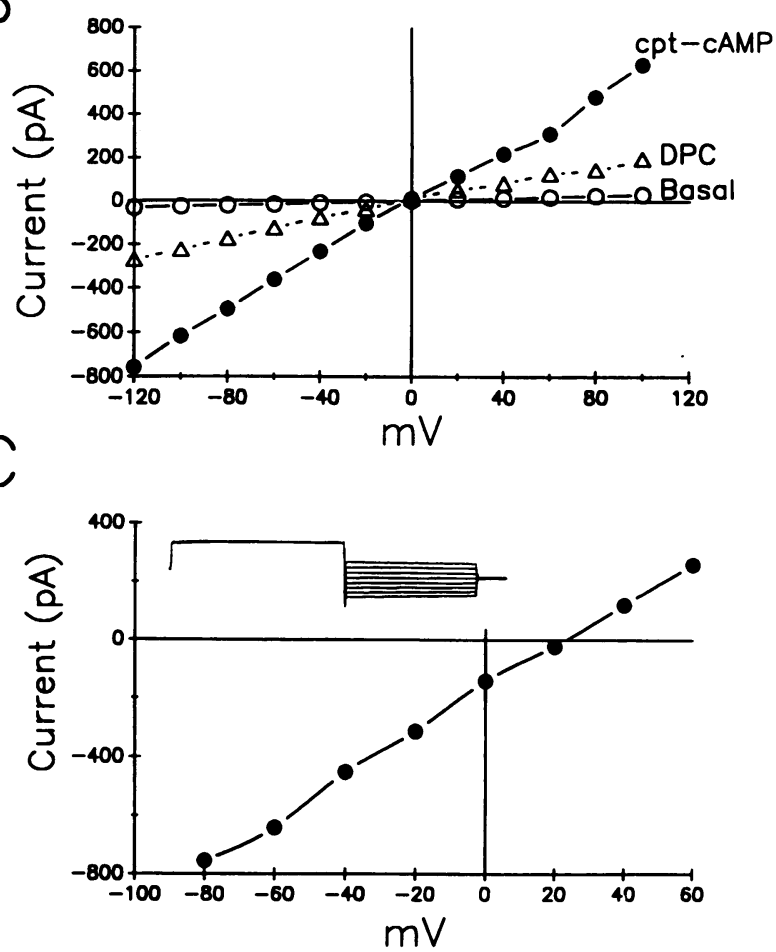

Figure 5. Effect of cpt-cAMP on membrane currents. Membrane currents $(A)$ and the current-voltage relation $(B)$ were measured in standard $\mathrm{Cl}^{-}$containing solutions under basal conditions (top in $A$, open circles in $B$ ), after exposure to cpt-cAMP $(500 \mu \mathrm{M})$ (middle in $A$, filled circles in $B$ ), and after exposure to DPC (bottom in $A$, open triangles in $B$ ). Activated currents were time independent and exhibited linear current-voltage relations. Tail currents ( inset, $C$ ) were measured in a seperate cell where extracellular $\mathrm{Cl}^{-}$was reduced to $26 \mathrm{mM}$ (by substitution with gluconate) resulting in a shift in reversal potential toward the new $\mathrm{Cl}^{-}$equilibrium potential.

15:15 plates $(P<0.01$ by paired $t$ test for each isotope, Fig. 6 $A$ ). When expressed as a percentage of basal efflux, the maximal increase for ${ }^{125}$ I efflux $(442 \pm 120 \%)$ was greater than for ${ }^{36} \mathrm{Cl}$ efflux ( $\left.122 \pm 15 \%\right)$. DIDS ( $\left.150 \mu \mathrm{M}, n=5\right)$ inhibited ionomycin-stimulated efflux by $48 \pm 9 \%$ for ${ }^{125} \mathrm{I}$ and $36 \pm 8 \%$ for ${ }^{36} \mathrm{Cl}$ $(P<0.01$ for each isotope $)$. These results were confirmed in a larger series of studies using ${ }^{125}$ I alone, where ionomycin increased ${ }^{125}$ I efflux in 18:21 $(86 \%, P<0.001)$ plates with an increase to $373 \pm 69 \%$ of basal levels. The increase was detected within $30 \mathrm{~s}$ and peaked within $1-2 \mathrm{~min}$. In nominally $\mathrm{Ca}^{2+}$-free media (no added $\mathrm{Ca}^{2+}, 1 \mathrm{mM}$ EGTA), ionomycin caused a small but significant increase in ${ }^{125}$ I efflux in 9:9 plates $(P$ $<0.01)$ to $135 \pm 7 \%$, but reexposure to extracellular $\mathrm{Ca}^{2+}$ caused an additional increase to $416 \pm 126 \%(P<0.01)$, suggesting that the effects of ionomycin depend, in part, on the presence of extracellular $\mathrm{Ca}^{2+}$.

In cells loaded with both isotopes, exposure to forskolin plus cpt-cAMP also caused a simultaneous increase in efflux of ${ }^{36} \mathrm{Cl}$ and ${ }^{125} \mathrm{I}$ in $16: 16$ plates $(P<0.02$ by paired $t$ test for each isotope, Fig. $6 \mathrm{~B}$ ). When expressed as a percentage of basal efflux, the maximal increase in ${ }^{125}$ I efflux $(107 \pm 39 \%)$ was less than for ${ }^{36} \mathrm{Cl}$ efflux ( $346 \pm 72 \%$ ). DIDS $(150 \mu \mathrm{M}, n=5)$ had no effect on cAMP-stimulated efflux (increased ${ }^{125}$ I by $12 \pm 2 \%$ and inhibited ${ }^{36} \mathrm{Cl}$ by $7 \pm 3 \%$, NS). In a larger series of studies using ${ }^{125}$ I alone, exposure to forskolin plus cpt-cAMP increased ${ }^{125}$ I efflux in $28: 36$ plates $(78 \%, P<0.01)$ to $152 \pm 17 \%$. The peak response occurred 2-3 min after exposure. These results confirm the presence of $\mathrm{Ca}^{2+}$ - and cAMP-regulated anion conductances in a significant portion of isolated cells, suggest that the permeability of ${ }^{125} \mathrm{I}$ is greater through the $\mathrm{Ca}^{2+}$-activated pathway as compared with the cAMP-activated pathway, and indicate that $150 \mu \mathrm{M}$ DIDS inhibits $\mathrm{Ca}^{2+}$-activated efflux but not cAMP-activated efflux.

Immunohistochemical detection of CFTR. The properties of the cAMP-dependent anion conductance resemble those associated with expression of CFTR in other cell types $(13,14$, 23,26 ). To examine whether bile duct epithelial cells contain CFTR, immunoblot analyses were performed in lysates from normal rat liver (Fig. 7, lane 1) and from rat liver containing increased numbers of bile duct epithelial cells (lane 2). Lysates of the human colonocyte cell line, T84, were used as a positive control because the properties of CFTR have been extensively characterized in this cell line using alpha-1468 (30). Specifically, the CFTR immunoblot signal in T84 cells is detected as a protein of $155-170 \mathrm{kD}$ (lane 3). This signal, which is known to represent the endogenous form of CFTR in T84 cells (30), resembles the predominant immunoblot signal detected in lysates of rat liver in which bile duct proliferation has been stimulated by ligation of the bile duct (lane 2). The immunoblot signal is not detected in normal rat liver (lane 1 ) and is not detected in duplicate immunoblots tested without primary antibody (not shown). Thus, the CFTR signal was markedly increased after bile duct ligation, suggesting that bile duct proliferation is associated with an increase in detectable CFTR.

Immunocytochemical methods were used to evaluate further the occurrence of CFTR in rat liver (Fig. 8). When cryosections of the same liver used for the immunoblot shown in Fig. 7 were tested with alpha-1468 (right), CFTR staining was 

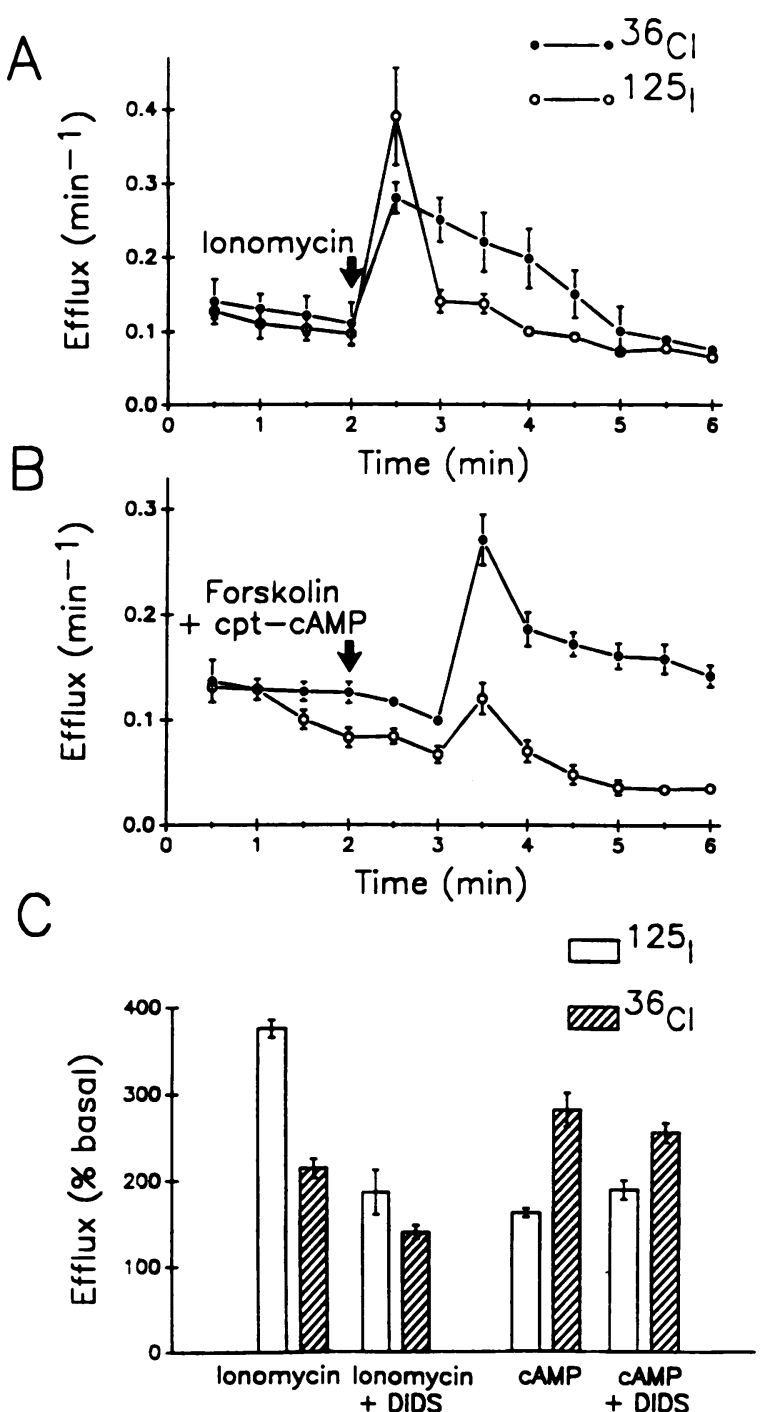

Figure 6. Isotope efflux. In these representative studies, simultaneous efflux of ${ }^{36} \mathrm{Cl}$ (closed circles) and ${ }^{125} \mathrm{I}$ (open circles) was assessed in cell monolayers. Exposure to ionomycin $(A)$ or to forskolin plus cptcAMP $(B)$ as described in Methods caused a simultaneous increase in efflux of both isotopes. The results are summarized as a percentage of basal efflux rate in $C$, which demonstrates that when measured in the same cells, ionomycin causes a greater increase in efflux of ${ }^{125} \mathrm{I}$ (open bars) as compared to ${ }^{36} \mathrm{Cl}$ ( hatched bars); ionomycin-stimulated efflux is inhibited by DIDS; cAMP (to refer to the forskolin plus cpt-cAMP mixture) causes a greater increase in efflux of ${ }^{36} \mathrm{Cl}$ as compared to ${ }^{125} \mathrm{I}$; and cAMP-stimulated efflux is not affected by DIDS. All points were measured in quadruplicate from a single preparation, and are presented as mean $\pm \mathrm{SE}$.

present and was localized to smaller ductlike cells. Similar groups of cells from a near serial section of the same specimen also stained positively for the bile duct cell marker CK-19 (left). alpha-1468 staining was specific in that it did not occur in sections stained either without alpha- 1468 or with alpha1468 plus competing peptide (not shown).

\section{Discussion}

Bile duct epithelia account for only $\sim 2 \%$ of cells in the liver, but in man the intrahepatic ductular network is estimated to be

$\sim 2 \mathrm{~km}$ in length. This corresponds to a large surface area where fluid and electrolyte transport could occur (8). Previous studies have demonstrated that the intrahepatic portion of the bile duct contributes importantly to bile formation $(1,5-7)$, but there is little information regarding the cellular mechanisms responsible. Unlike renal tubular preparations or isolated pancreatic ducts (12), micropuncture studies to sample luminal fluid and measure transmembrane potentials have not been possible because of the small size and intrahepatic location of BDE cells. Consequently we have evaluated the properties of isolated cells in short-term culture using techniques that permit measurement of membrane currents in cells too small for conventional intracellular recording.

The principal findings are that bile duct epithelial cells exhibit both $\mathrm{Ca}^{2+}$ - and cAMP-stimulated $\mathrm{Cl}^{-}$currents which differ in their biophysical properties. The cAMP-stimulated anion efflux pathway measured in single cells using electrophysiologic techniques and in cells in short-term culture using isotope efflux techniques appears similar to that associated with CFTR, and CFTR is detectable in biliary cells by both immunoblot and immunoperoxidase staining. These similarities to established $\mathrm{Cl}^{-}$secretory cells suggest that $\mathrm{Ca}^{2+}$ - and cAMP-dependent $\mathrm{Cl}^{-}$channels may participate in the control of fluid and electrolyte transport across the intact biliary epithelium.

Although isolated duct cells were morphologically homogeneous, basal currents revealed three distinct patterns with outward rectification of the current-voltage relation in $\sim 57 \%$, small linear currents in $\sim 31 \%$, and inward rectification of the current-voltage relation in $\sim 12 \%$ (Fig. 1). While a contribution from nonductular cells cannot be eliminated, it seems

\section{3}

$205 \mathrm{kDa}$ -

$116 \mathrm{kDa}$ -

$97 \mathrm{kDa}-$

$66 \mathrm{kDa}-$
Figure 7. Detection of CFTR in rat liver by immunoblot. CFTR was detected using alpha-1468, an affinity-purified antibody raised against a peptide containing the $\mathrm{COOH}$-terminal sequence of CFTR. Lane 1 contains lysate from a normal rat liver; lane 2 contains lysate from a rat after bile duct ligation for $6 \mathrm{w}$ to increase the number of bile duct cells, and lane 3 contains lysate from T84 cells as a positive control. $100 \mu \mathrm{g}$ of solubilized protein was loaded per lane. CFTR was detected as a heterogeneous band between 150 and $165 \mathrm{kD}$. The small difference in electrophoretic mobility between the liver preparation and human CFTR was observed consistently. 

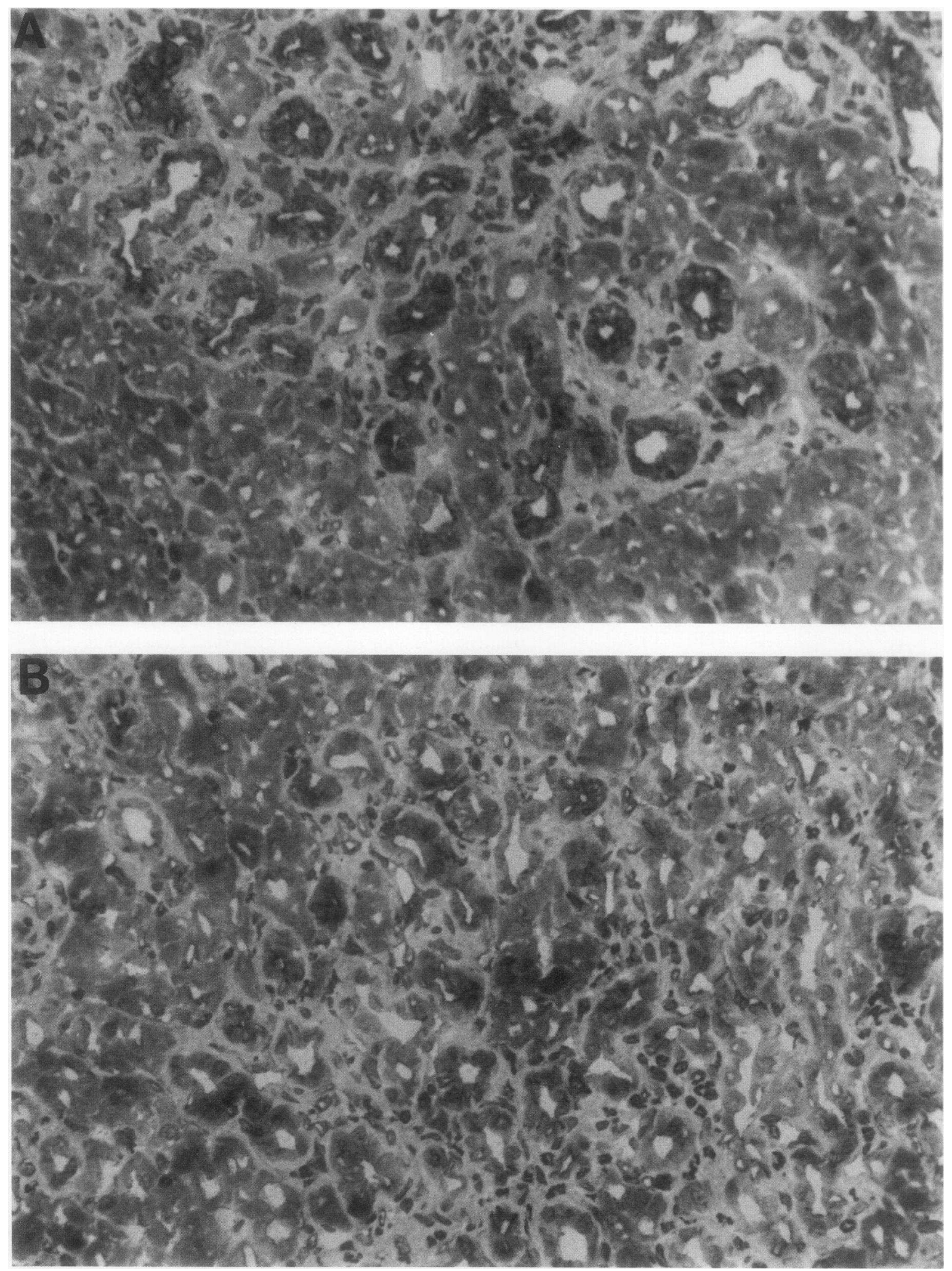

Figure 8. Detection of CFTR in rat bile duct epithelial cells by immunoperoxidase staining with alpha-1468. Cryosections were obtained from a snap-frozen aliquot of the same liver used in Fig. 7. ( $A$ ) Staining for the bile duct cell marker CK-19 is positive in cells that form branching intrahepatic ducts. (B) Staining for CFTR shows localization to similar structures but not hepatocytes. $\times 200$.

more likely that these represent populations of ductular cells which differ in their basal properties. This may reflect different cellular functions, effects of the isolation procedure, or different stages of maturation.
The properties of the outwardly rectified current closely resemble $\mathrm{Ca}^{2+}$-dependent $\mathrm{Cl}^{-}$currents described in several $\mathrm{Cl}^{-}$secreting epithelia including rat lacrimal glands (34), the intestinal T84 cell line (13), and airway epithelia (14). Out- 
wardly rectified currents were not detected when cytosolic $\mathrm{Ca}^{2+}$ concentration was decreased to $<10 \mathrm{nM}$ by increasing pipette EGTA to $5 \mathrm{mM}$. In contrast, exposure to the $\mathrm{Ca}^{2+}$ ionophore ionomycin rapidly increased currents in 5:7 (71\%) attempts. Currents reversed near the equilibrium potential for $\mathrm{Cl}^{-}$, showed time-dependent activation after depolarizing voltage steps, and were inhibited by the $\mathrm{Cl}^{-}$channel blocker DPC. In addition, the reversal potential of tail currents showed a strong dependence on the concentration of $\mathrm{Cl}^{-}$in the bath solution (Fig. 3). The observed slope of $\sim 42 \mathrm{mV}$ per log change in bath $\mathrm{Cl}^{-}$concentration (compared to the ideal Nernstian slope of $58 \mathrm{mV}$ for a $\mathrm{Cl}^{-}$selective membrane) likely underestimates the $\mathrm{Cl}^{-}$selectivity of the responsible channels as nonselective membrane currents or current leak also contribute to measured values.

In cells in short-term culture, ionomycin caused a simultaneous and DIDS-inhibitable increase in efflux of both ${ }^{36} \mathrm{Cl}$ and ${ }^{125} \mathrm{I}$, but the increase in ${ }^{125} \mathrm{I}$ efflux was greater when measured in the same cells. This suggests that the permeability of ${ }^{125} \mathrm{I}$ through the $\mathrm{Ca}^{2+}$-activated anion efflux pathway is greater than ${ }^{36} \mathrm{Cl}$ as reported in established Cl-secretory cells $(14,22$, 34). The effects of ionomycin on ${ }^{125} \mathrm{I}$ efflux were diminished in the nominal absence of bath $\mathrm{Ca}^{2+}$, but recovered in the presence of $\mathrm{Ca}^{2+}$, suggesting that the effects depend in part on influx of extracellular $\mathrm{Ca}^{2+}$. While ionomycin-stimulated ${ }^{125} \mathrm{I}$ efflux was transient, lasting only $30-150 \mathrm{~s}$, whole cell currents in individual cells remained increased for $5 \mathrm{~min}$ or more suggesting that the transient nature of the ${ }^{125} \mathrm{I}$ response may be caused by depletion of intracellular ${ }^{125}$ I or other factors and not transient activation of channels.

Exposure of cells to forskolin or cpt-cAMP increased currents in 11:16 (69\%) attempts, but the biophysical properties were distinct in that currents were time independent and generally exhibited linear current-voltage relations. This is similar to cAMP-activated $\mathrm{Cl}$ currents in T84 monolayers (13), airway cells (14), and cells expressing exogenous CFTR (23). cAMP-stimulated currents and tail currents each reversed near the equilibrium potential for $\mathrm{Cl}^{-}$and were inhibited by DPC. In view of the difficulties performing ion substitutions in these cells, patches were subsequently excised after activation of currents to form high resistance seals to assure that the observed increase in linear currents was not related to loss of seal resistance. In addition, demonstration of cAMP-stimulable increases in ${ }^{36} \mathrm{Cl}$ and ${ }^{125}$ I efflux in cultured cells provides strong support for the electrophysiologic observations. In contrast to ionomycin-stimulated efflux, cAMP-stimulated efflux was unaffected by DIDS and appeared to have greater permeability to ${ }^{36} \mathrm{Cl}$ as compared to ${ }^{125} \mathrm{I}$.

Based on these observations, additional studies were performed to determine whether the cAMP-activated anion conductance is associated with endogenous expression of CFTR. Immunoblot analyses of rat liver detected CFTR as a heterogeneous $150-165 \mathrm{kD}$ protein that is most abundant in samples containing increased numbers of bile duct epithelial cells. Localization to bile duct cells was confirmed by immunoperoxidase staining which showed that the pattern of CFTR staining correlated closely with the pattern of staining seen with the bile duct cell marker CK-19. Staining was not detected in hepatocytes. In aggregate, these observations suggest that the cAMPregulated anion conductance in bile duct cells may be caused by endogenous expression of CFTR. However, identification of low conductance $\mathrm{Cl}^{-}$channels with appropriate properties
(23) would be required to establish this point more conclusively. While a separate population of high conductance anion channels with linear current-voltage relations have been described in these cells (27), these do not appear to be regulated by cytosolic cAMP or $\mathrm{Ca}^{2+}$. Consequently, it seems unlikely that high conductance anion channels contribute importantly to the regulated currents observed in these studies.

The presence in bile duct cells of $\mathrm{Ca}^{2+}$ - and cAMP-regulated $\mathrm{Cl}^{-}$currents with properties similar to those in established $\mathrm{Cl}^{-}$secretory cells suggests that regulated $\mathrm{Cl}^{-}$channels may contribute to ductular secretion. However, several qualifications of these studies merit emphasis. First, cell isolation disrupts epithelial integrity and attempts to induce tight junction formation in culture have been unsuccessful. Consequently, the contribution and proposed apical location of regulated $\mathrm{Cl}^{-}$currents needs to be confirmed in an intact epithelial preparation when this becomes available. Second, measurement of whole cell currents is limited by the small size of these cells and the tendency for seals to deteriorate during superperfusion and ion substitution. This may reflect effects on the membrane of prolonged exposure to the detergent effects of bile salts or the stringent conditions required for cell isolation. In these studies, characterization of whole cell recordings was supported by isotopic and immunologic techniques. However, the need to characterize and localize the single channels responsible for the $\mathrm{Ca}^{2+}$ - and cAMP-activated currents is apparent.

These observations are consistent with recent studies which support a role for duct cells in bile formation through secretion of fluid and electrolytes $(1,5-7)$. By analogy with established $\mathrm{Cl}^{-}$secretory epithelia $(12-14,16)$, activation of $\mathrm{Cl}^{-}$channels in the apical membrane by $\mathrm{Ca}^{2+}$ - and cAMP-dependent signaling pathways would stimulate efflux of $\mathrm{Cl}^{-}$to the lumen and generate a lumen-negative transepithelial potential favoring $\mathrm{Na}+$ and water secretion and possibly $\mathrm{Cl}^{-} / \mathrm{HCO}_{3}$-exchange $(12,16,36)$. Moreover, abnormal cAMP-dependent regulation of the responsible channels might contribute to the pathogenesis of cholestatic liver disease in cystic fibrosis $(10,11,17)$ and other disorders which affect bile duct secretory function. Identification of the individual channels and regulatory pathways which contribute to membrane $\mathrm{Cl}^{-}$transport represents a potential target for pharmacologic manipulation of ductular secretion.

\section{Acknowledgments}

The authors wish to thank Dr. Allen Mangel for helpful discussions, Dr. Marwan Farouk for assistance in preparation of cells, Kathleen Dittrich for immunohistochemical studies, and Jolanta Kole for immunoblot studies.

This work was supported in part by grants from the National Institutes of Health (DK43278, DK07568, DK40701), Cystic Fibrosis Foundation, Veterans Administration, American Diabetes Association (J. G. Fitz), and an American Gastroenterological Association/G.D. Searle Research Scholar Award (J. G. Fitz).

\section{References}

1. Nathanson, M. H., and J. L. Boyer. 1991. Mechanisms and regulation of bile secretion. Hepatology. 14:551-556.

2. Sirica, A. E., G. A. Mathis, N. Sano, and L. W. Elmore. 1990. Isolation, culture, and transplantation of intrahepatic biliary epithelial cells and oval cells. Pathobiology. 58:44-64.

3. Sirica, A. E., C. A. Sattler, and H. P. Cihla. 1985. Characterization of a primary bile ductular cell culture from livers of rats during extrahepatic cholestasis. Am. J. Pathol. 120:67-78.

4. Slott, P. A., M. H. Liu, and N. Tavoloni. 1990. Origin, pattern, and mecha- 
nism of bile duct proliferation following primary obstruction in the rat. Gastroenterology. 99:466-477.

5. Alpini, G., R. Lenzi, L. Sarkozi, and N. Tavoloni. 1988. Biliary physiology in rats with bile ductular cell hyperplasia. J. Clin. Invest. 81:569-578.

6. Alpini, G., R. Lenzi, W. R. Zhai, P. A. Slott, M. H. Liu, L. Sarkozi, and N. Tavoloni. 1989. Bile secretory function of intrahepatic biliary epithelium in the rat. Am. J. Physiol. 257:G124-G133.

7. Ishii, M., B. Vroman, and N. F. LaRusso. 1989. Isolation and morphologic characterization of bile duct epithelial cells from normal rat liver. Gastroenterology. 97:1236-1247.

8. Kumar, U., and T. W. Jordan. 1986. Isolation and culture of biliary epithelial cells from the biliary tract fraction of normal rats. Liver. 6:369-378.

9. Farouk, M., S. R. Vigna, D. C. McVey, and W. C. Meyers. 1992. Localization and characterization of secretin binding sites expressed by rat bile duct epithelium. Gastroenterology. 102:963-968.

10. Ghishan, F. K., and H. L. Greene. 1982. Inborn errors of metabolism that lead to permanent liver injury. In Hepatology. D. Zakim and T. D. Boyer, editors. W. B. Saunders Co., Philadelphia, PA. 1084-1137.

11. Quinton, P. M. 1990. Cystic fibrosis: a disease in electrolyte transport. FASEB (Fed. Am. Soc. Exp. Biol.) J. 4:2709-2717.

12. Ashton, N., B. E. Argent, and R. Green. 1991. Characteristics of fluid secretion from isolated rat pancreatic ducts stimulated with secretin and bombesin. J. Physiol. 435:533-546.

13. Cliff, W. H., and R. Frizell. 1990. Separate $\mathrm{Cl}^{-}$conductances activated by cAMP and $\mathrm{Ca}^{2+}$ in $\mathrm{Cl}^{-}$secreting epithelial cells. Proc. Natl. Acad. Sci. USA. 87:4956-4960.

14. Anderson, M. P., and M. J. Welsh. 1991. Calcium and cAMP activate different chloride channels in the apical membrane of normal and cystic fibrosis epithelia. Proc. Natl. Acad. Sci. USA. 88:6003-6007.

15. Hwang, T.-C., L. Lu, P. L. Zeitlin, D. C. Gruenert, R. Huganir, and W. B. Guggino. 1989. $\mathrm{Cl}^{-}$channels in CF: lack of activation by protein kinase $\mathrm{C}$ and cAMP-dependent protein kinase. Science (Wash. DC). 244:1351-1353.

16. Gray, M. A., J. R. Greenwell, and B. E. Argent. 1988. Secretin-regulated chloride channel on the apical plasma membrane of pancreatic duct cells. $J$. Membr. Biol. 105:131-142.

17. Welsh, M. J. 1990. Abnormal regulation of ion channels in cystic fibrosis epithelia. FASEB (Fed. Am. Soc. Exp. Biol.) J. 4:2718-2725.

18. Marino, C. R., L. M. Matovik, F. S. Gorelick, and J. A. Cohn. 1991. Localization of cystic fibrosis transmembrane conductance regulator in pancreas. J. Clin. Invest. 88:712-716.

19. Cohn, J. A., O. Melhus, L. J. Page, K. Dittrich, and S. Vigna. 1991. CFTR development of high-affinity antibodies and localization in sweat gland. Biochem. Biophys. Res. Commun. 181:36-43.

20. Fitz, J. G., and B. F. Scharschmidt. 1987. Intracellular chloride activity in rat hepatocytes in vivo: relationship to membrane potential and bile flow. Am.J. Physiol. 252:G699-G706.

21. Hamill, O. P., A. Marty, E. Neher, B. Sakmann, and F. J. Sigworth. 1981. Improved patch clamp techniques for high-resolution current recording from cells and cell-free membrane patches. Pfleugers Arch. Eur. J. Physiol. 391:85100.
22. Venglarik, C. J., R. J. Bridges, and R. A. Frizell. 1990. A simple assay for agonist-regulated $\mathrm{Cl}$ and $\mathrm{K}$ conductances in salt-secreting epithelial cells. $\mathrm{Am}$. J. Physiol. 259:C358-C364.

23. Berger, H. A., M. P. Anderson, R. J. Gregory, S. Thompson, P. W. Howard, R. A. Maurer, R. Mulligan, A. E. Smith, and M. J. Welsh. 1991. Identification and regulation of the cystic fibrosis transmembrane conductance regulatorgenerated chloride channel. J. Clin. Invest. 88:1422-1431.

24. Rommens, J. M., M. C. Ianuzzi, B.-S. Kerem, M. L. Drumm, G. Melmer, M. Dean, R. Rozmahel, J. L. Cole, D. Kennedy, N. Hikada, et al. 1989. Identification of the cystic fibrosis gene: chromosomal walking and jumping. Science (Wash. DC). 245:1059-1065.

25. Riordan, J. R., J. M. Rommens, B.-S. Kerem, N. Alon, R. Rozmahel, Z. Grzelczak, J. Zielenski, S. Lok, N. Plavsic, J.-L. Chou, et al. 1989. Identification of the cystic fibrosis gene: cloning and characterization of complementary DNA. Science (Wash. DC). 245:1066-1073.

26. Anderson, M. P., R. J. Gregory, S. Thompson, D. Souza, S. Paul, R. C Mulligan, A. E. Smith, and M. J. Welsh. 1991. Demonstration that CFTR is a chloride channel by alteration of its anion selectivity. Science (Wash. DC). 253:202-205.

27. McGill, J., S. Basavappa, and J. G. Fitz. 1992. Characterization of highconductance anion channels in rat bile duct epithelial cells. Am. J. Physiol. 262:G703-G710.

28. Rutenberg, A. M., H. Kim, J. W. Fishbein, J. S. Hanker, H. L. Wasserkrug, and A. M. Seligman. 1969. Histochemical and ultrastructural demonstration of gamma-glutamyl transpeptidase. J. Histochem. Cytochem. 17:517-526.

29. Lowry, O. H., N. J. Rosenberg, A. L. Farr, and R. J. Randall. 1951. Protein measurements with the Folin phenol reagent. J. Biol. Chem. 193:265275.

30. Cohn, J. A., A. C. Nairn, J. Kole, O. Melhus, and C. R. Marino. 1992. Characterization of the cystic fibrosis transmembrane conductance regulator in a colonocyte cell line. Proc. Natl. Acad. Sci. USA. 89:2340-2344.

31. Marino, C. R., L. Horesh, D. Clark, L. M. Matovik, F. S. Gorelick, and J. A. Cohn. 1991. Localization of the cystic fibrosis transmembrane conductance regulator to pancreas. Gastroenterology. 100:A287.

32. Tata, F., P. Stanier, C. Wicking, S. Halford, H. Kruyer, N. J. Lench, P. J. Scambler, C. Hansen, J. C. Braman, R. Williamson, and B. J. Wainwright. 1991. Cloning the mouse homolog of the human cystic fibrosis transmembrane conductance regulator gene. Genomics. 10:301-307.

33. Chang, D., P. S. Hsieh, and D. C. Dawson. 1988. Calcium: a program in basic for calculating the composition of solutions with specified free concentrations of calcium, magnesium, and other divalent cations. Comput. Biol. Med. 5:351-366.

34. Evans, M. G., and A. Marty. 1986. Calcium-dependent chloride currents in isolated cells from rat lacrimal glands. J. Physiol. 378:437-460.

35. Schoppa, N., S. R. Shorofsky, F. Low, and D. J. Nelson. 1989. Voltagegated chloride currents in cultured canine trachael epithelial cells. J. Membr. Biol. 108:73-90.

36. Strazzabosco, M., A. Mennone, and J. L. Boyer. 1991. Intracellular pH regulation in isolated rat bile duct epithelial cells. J. Clin. Invest. 87:1503-1512. 